\title{
COMPARISON OF THE RESULTS OF PUMPING AND TRACER TESTS IN A KARST TERRAIN
}

\author{
Alireza Nassimi and Zargham Mohammadi* \\ Department of Earth Sciences, Shiraz University, Faculty of Science, Adabiat Crossroads, 7146713565; \\ Shiraz, Fars Province, Iran
}

\begin{abstract}
Pumping and tracer tests are commonly used to measure aquifer parameters such as hydraulic conductivity. Hydraulic conductivity is, however, difficult to characterize; especially in heterogeneous karst terrain. In this research, results of pumping and tracer tests are combined to determine hydraulic conductivities of the karst terrain at the Salman Farsi Dam Site. Pumping test data were analyzed by dual-porosity analytical models. The tracer tests were used to determine seepage velocities based on the assumption of Darcy's law, with calculated Reynolds numbers consistent with laminar flow. Geometric means of the hydraulic conductivities calculated from tracer tests were consistently higher than results derived from pumping tests. Movement of injected dye in a natural groundwater flow system is strongly controlled by preferential flow paths; therefore the estimated hydraulic conductivity is mainly affected by major dissolution openings. However, estimated hydraulic conductivity based on the pumping-test data is representative of the average hydraulic conductivity. In addition, Lugeon (or packer) tests were used to delineate the distribution of hydraulic conductivity within three boreholes.
\end{abstract}

\section{INTRODUCTION}

Aquifers in karst terrains are generally heterogeneous, anisotropic, and complex. These aquifers have an interconnected array of fractures and dissolution routes (Cacas et al., 1990; Hestir and Long, 1990). The dual-porosity model is an effective tool for modeling karst systems (Kovács and Sauter, 2007). The dual-porosity model was initially proposed by Barenblatt et al. (1960) and developed in detail by Streltsova-Adams (1978) and Gringarten (1982). The heterogeneity of karst aquifers, where solutional pathways have orders-of-magnitude higher hydraulic conductivity than the surrounding matrix porosity, requires careful application of analytical tools.

A pumping test induces a perturbation to an aquifer by pumping from a well, while at the same time measuring aquifer responses in the form of head variations (Renard et al., 2009). Selection of appropriate analytical and numerical models is a key part of calculating the hydraulic characteristics, such as hydraulic conductivity, transmissibility, and storage coefficient, of the aquifer (Renard et al., 2009). Hydrodynamic coefficients of aquifers in water resource studies vary of many orders of magnitude, and small errors in the calculation of these coefficients can produce errors of several orders of magnitude in budgets and numerical models of groundwater. Pumping tests do, however, directly produce results for transmissivity and storage, which are the key factors in groundwater studies (Drew and Goldscheider, 2007).

A simultaneous plot of the drawdown and the logarithmic derivative of the drawdown as a function of time in a log-log scale is called a diagnostic plot (Bourdet et al., 1983). A conceptual model for interpretation of the pumping test data is selected based on the diagnostic plot technique combined with knowledge of the local geology (Samani et al., 2006; Renard et al., 2009; Hammond and Field, 2014). The major advantage of diagnostic plots is that they provide a unified procedure to interpret pumping test data (Renard et al., 2009). The main limitation of the drawdown derivative approach to unsteady test analysis is the discrete measurements of drawdown data from individual times, because the rate of change of drawdown currently cannot be measured directly (Samani et al., 2006). Modern data loggers can produce much better temporal resolution than conventional hand measurements, as well as more consistent vertical resolution.

Tracer tests are a powerful tool for determining the origin, movement, and destination of groundwater in hydrogeological investigations, particularly in karst areas (Benischke et al., 2007). In hydrogeology, a tracer is any kind of substance in the water or some other measurable property of the water. It can be used to obtain information on the groundwater flow and impurity transport (Benischke et al., 2007). Through tracer testing, longitudinal and transverse dispersivity and the ratio of hydraulic conductivity and effective porosity can be determined (Lee et al., 2003).

Tracer tests have many advantages, allowing the direct determination of flow routes and velocities and the determination of the catchment area of springs (Drew and Goldscheider, 2007; Löfgren et al., 2007). Tracer tests do have limitations, especially where no tracer is recovered (negative traces), where tracers from other studies interfere

* Corresponding author: zmohammadi@shirazu.ac.ir 


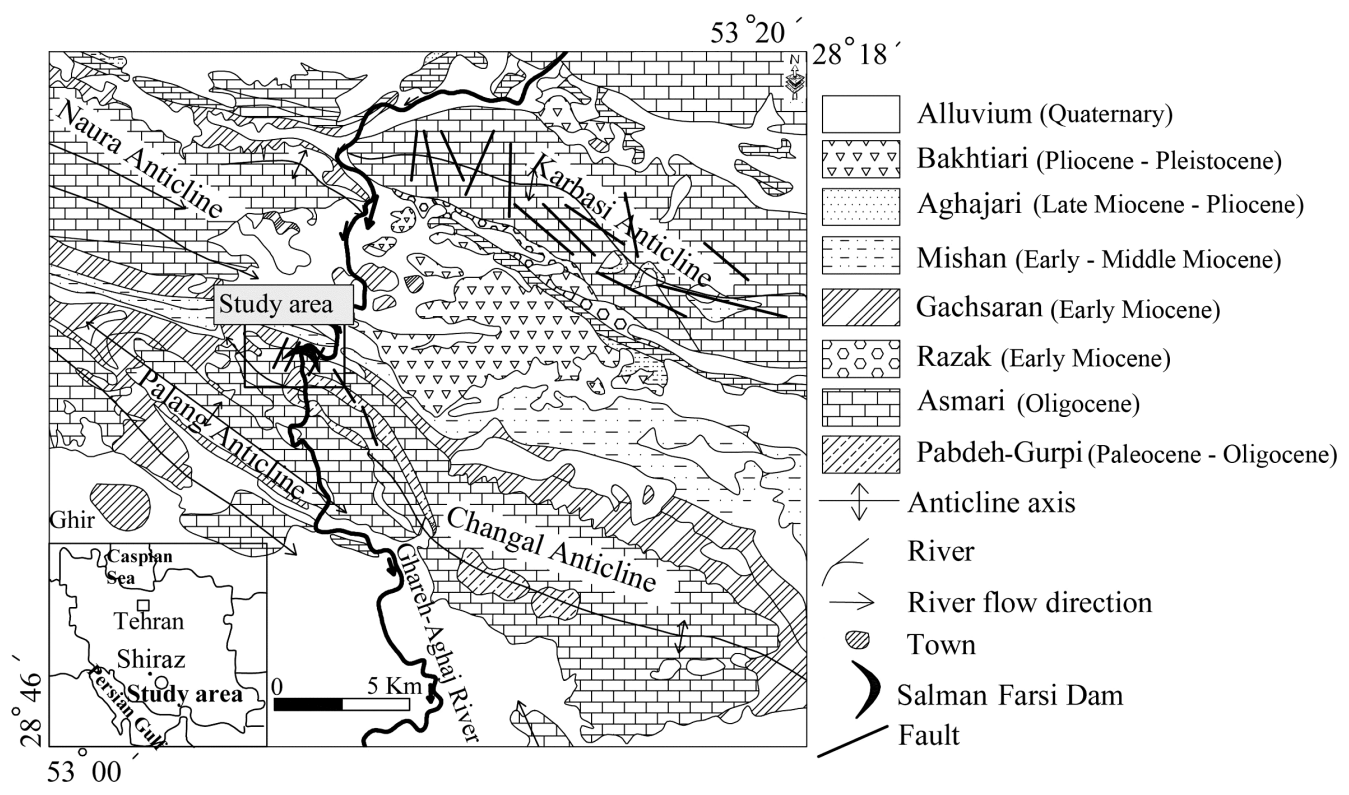

Figure 1. General geological map of the study area (modified from Mohammadi et al., 2010).

(false positives), where deep hydrogeological settings provide few monitoring points, and where high concentrations of tracer may impact potable water supplies (Drew and Goldscheider, 2007; Löfgren et al., 2007).

The combined application of pumping and tracer tests was conducted first by De Laguna (1970) in a two-layered sandy aquifer where a forced gradient tracer test was used to determine what proportion of the pumped water was coming from each sandy aquifer. Later applications of this dual method include Dann et al. (2008) in a channelized aquifer and Thorbjarnarson et al. (1998) in a stratified aquifer, who showed higher hydraulic conductivity values from tracer tests in comparison to pumping tests, though studies by Niemann and Rovey (2000) in an area of glacial outwash and by Rovey and Niemann (2005) under laboratory conditions in a sand tank have shown the opposite result. Vandenbohede and Lebbe (2003), in a phreatic coastal plain aquifer, found good agreement between pumping and tracer tests. Given the dual porosity common in karst terrains, a combined pumping and tracer tests allow evaluation of hydraulic conductivities in solutional conduits within the aquifer matrix. Tracer tests directly measure the groundwater flow velocity better by taking into account and compensating for heterogeneity (Vandenbohede and Lebbe, 2003; Drew and Goldscheider, 2007).

Technical projects in a karst terrain normally face crucial technical, managerial, and political challenges due to the complexity of the karst environment. Some engineering problems in karst environments are caused by the presence of caverns, sinkholes, shafts, and other preferential flow paths that influence groundwater hydraulics (Milanovic, 2002; Parise et al., 2008, 2015a; Gutiérrez et al., 2014).

The objectives of this research were the comparison of the hydraulic-conductivity values derived from pumping and tracer tests and the evaluation of the effect of karst development on the values obtained from selected tests at the Salman Farsi Dam Site (SFDS), Fars Province, southern Iran.

\section{Materials ANd Methods}

\section{Geological Setting}

The SFDS is located near Ghir city, $190 \mathrm{~km}$ from the city of Shiraz in Fars Province, in south Iran (Fig. 1). The Salman Farsi Dam is an arch-gravity dam with $125 \mathrm{~m}$ height and reservoir volume of 1,400 million cubic meters that was constructed on the Ghareh-Aghaj River in Fars Province.

The study area is situated at the Changal Anticline (Fig. 1) of the Zagros Folded Belt, which is 200 to $300 \mathrm{~km}$ wide and formed in the Upper Cenozoic. The SFDS is on the northern limb of the Changal Anticline, which trends NW-SE. The stratigraphy and structural framework of the study area were studied in detail by Fars Regional Water Authority (1990), Rahbari and Bagheri (1996), Vucković and Milanović (2001), and Fazeli (2007). In this region, the strata are from the Upper Cretaceous to the present time. Overburden includes slopewash deposits of angular rock fragments and alluvial terraces of cobbles, gravel, sand, and silt located along the rivers. The Bakhtiari Formation (Pliocene-Pleistocene) includes conglomerate of heterogeneous particles with calcareous cement and has a large extent within the Salman Farsi reservoir area. The Mishan Formation (early to mid-Miocene) includes gray to green marls, shaly limestone, and marly limestone outcropping in the bottom and the banks of the reservoir (Vuckovic and Milanović, 2001). The Razak Formation (Miocene) consists of gypsum, marl, siltstone, and shale with marly limestone. 
Table 1. Summary of the tracer tests parameters at the SFDS (extracted from Khalaj Amirhosseini, 1997).

\begin{tabular}{|c|c|c|c|}
\hline $\begin{array}{l}\text { Injection } \\
\text { Point }\end{array}$ & Sampling Points & Detection Points & $\begin{array}{l}\text { Tracer } \\
\text { Used }\end{array}$ \\
\hline QR F & $\begin{array}{l}\text { QR 8, QR 12, QR 25, QR 28, QR 32, QR 34, QR 55, } \\
\text { P.W. 2, Springs diversion tunnel, The river at location the dam, } \\
\text { QR 22, QR 26, G 6, The river at location bridge Abnema }\end{array}$ & No detection & Uranine \\
\hline QR 51 & $\begin{array}{l}\text { QR 8, QR 12, QR 25, QR 28, QR 32, QR 34, QR 55, } \\
\text { P.W. 2, Springs diversion tunnel, The river at location the dam, } \\
\text { QR 22, QR 46, G 6, The river at location bridge Abnema }\end{array}$ & $\begin{array}{l}\text { Springs diversion } \\
\text { tunnel }\end{array}$ & Rhodamin B \\
\hline QR 56 & $\begin{array}{l}\text { QR 53, QR 54, Spring Yargh, River upstream of the injection } \\
\text { point, River downstream of the injection point }\end{array}$ & No detection & Uranine \\
\hline QR 32 & $\begin{array}{l}\text { QR 8, QR 12, QR 25, QR 28, QR F, QR 34, QR 55, } \\
\text { P.W. 2, Springs diversion tunnel, The river at location the dam, } \\
\text { QR 22, QR 26, G 6, The river at location bridge Abnema }\end{array}$ & $\begin{array}{l}\text { QR 28, The river at } \\
\text { location the dam }\end{array}$ & $\mathrm{KCl}$ \\
\hline QR 28 & $\begin{array}{l}\text { QR 8, QR 12, QR 25, QR F, QR 32, QR 34, QR 55, } \\
\text { P.W.2, Springs diversion tunnel, The river at location the dam, QR 22, } \\
\text { QR 26, G 6, The river at location bridge Abnema }\end{array}$ & QR 8, QR 55 & $\mathrm{NaCl}$ \\
\hline
\end{tabular}

Upstream of the dam site the dip of the Razak deposits varies from 55 to 65 degrees. This formation is widespread in the reservoir area. The Asmari Formation (OligoceneMiocene) is dominated by limestones and is divided into Upper, Middle, and Lower units. The Upper Asmari, consisting of shelly limestone, marl, and marly limestone, outcrops upstream of the dam axis, forming the eastern and western reservoir banks (Fazeli, 2007). The Middle Asmari is about $180 \mathrm{~m}$ thick and composed of limestone calcarenite, cherty limestone, and nomolitic and oolitic limestones as well as a small number of marl and marly limestone interbeds. The dam and its appurtenances, including grouting curtain, are on the Middle Asmari, with its great lithological diversity and highly developed karst features such as conduits, big caverns, and chimneys. The Lower Asmari is found below the dam site and includes regularly bedded limestone alternating with marls at the top, and thin to very thin limestone and marly layers at the bottom (Fazeli, 2007). The relatively impermeable Pabdeh-Gurpi Formation (Paleocene to Oligocene) contains purple shale and marl with thin clayey and marly limestone interbeds. Outcrops of Pabdeh-Gurpi are found about $600 \mathrm{~m}$ downstream of the dam axis in the river bed section.

\section{Hydrogeologic Setting}

The hydrogeology of the study site was described by Fars Regional Water Authority (1994), Aghili and Meidani (1998), Milanović et al. (2002), and Fazeli (2007). Tectonics are the major control of karst structure and speleogenesis of the karst massif. At the initial stage of karstification (fractured limestone aquifer), groundwater movement through the fractured limestone aquifer created dissolutional enlargement. Therefore, cave systems are composed of many segments of interconnected nets of discontinuities, such as bedding planes, joints and shear fractures, faults, and their intersections. These structural elements play a key role in the initial stage of karstification by directing the groundwater flows (Vucković and Milanović, 2001; De Waele et al., 2011; Parise et al., 2015b; Taheri et al., 2015). The Upper and Lower Asmari have low permeability due to the existence of some marly layers. The Middle Asmari contains a greater proportion of pure limestone than the Upper and Lower Asmari limestone. Brittle deformation is more predominant in the Middle Asmari, producing ample pathways for groundwater flow (Fazeli, 2007). The Middle Asmari constitutes the main aquifer system at the SFDS and is confined by the Upper Asmari at the SFDS (Aghili and Meidani, 1998; Vucković and Milanović, 2001). Temperature was $38{ }^{\circ} \mathrm{C}$ in the pumping well (QR 8) during the pumping test. Average temperature was $28.4{ }^{\circ} \mathrm{C}$ in the injection and detection points at the SFDS during the tracer test. Before the construction of the Salman Farsi Dam, several springs and boreholes were known to discharge into the Ghareh-Aghaj River from the Asmari Formation; the sum of discharge of these springs and boreholes was about $8 \mathrm{~L} \mathrm{~s}^{-1}$ (Milanović et al., 2002).

\section{DATA UsED}

Five tracer tests were performed at the SFDS from November 1996 to February 1997 by the Water Research Center of the Ministry of Power. Table 1 lists the injection and sampling points and the detections, if any (Fig. 2).

One pumping test was conducted in well QR 8, and drawdowns were measured in the six observation wells QR 49, QR 47, QR 22, QR 28, QR 25 and QR 55 (Fig. 2) on November 1997 by the Mahab Ghodss Consulting Engineering Company. Table 2 shows the radial distance of the observation wells from the pumping well and some of their characteristics. Lugeon tests were done in three of the boreholes $(\mathrm{QR}$ 22, QR 28 and QR 32) that were also used in the pumping and tracer tests (Fars Regional Water Authority, 1995b). 


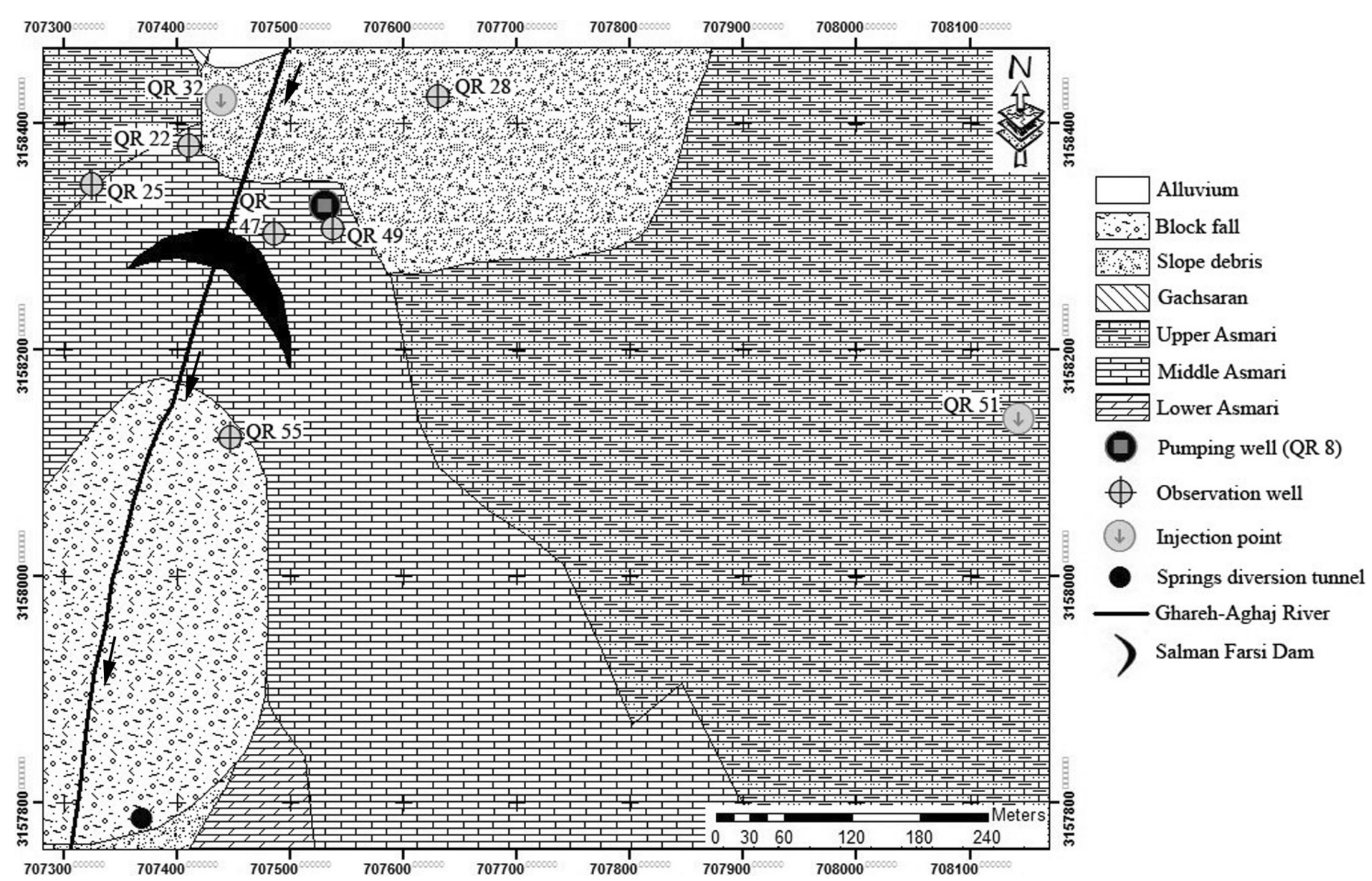

Figure 2. Locations of some of the wells used in the tracer tests, plus the springs diversion tunnel, and the wells used to measure the drawdown from pumping well QR 8.

\section{RESUlTS}

\section{Natural Gradient Tracer Tests}

Tracer tests directly measure groundwater flow velocities, providing a measure of range of velocities and a corresponding apparent hydraulic conductivity. Therefore tracer tests provide an important calibration of groundwater flow models in karst (Ghasemizadeh et al., 2012). Distance from the injection point to the detection point $(x)$ and time of the center of tracer mass $\left(t_{c}\right)$ were used for computation of mean groundwater velocity $v=x / t_{c}$ in Table 3 . Time of the center of tracer mass was extracted from breakthrough curves (for example Fig. 3). Geometric means of porosity (n) and the diameter of the channels, fractures, and conduits (D) were assumed $10.55 \%$ and $0.1 \mathrm{~m}$ at the SFDS, respectively according to Fars Regional Water Authority (1995a) and Nazari (2008).

The Reynolds number $\left(R_{e}\right)$ is a dimensionless parameter that determines the type of flow regime, laminar or turbulent, with formula $R_{e}=\rho v D / \mu$ appropriate for pipe of

Table 2. Some characteristics of the pumping well and observation wells at the SFDS (Aghili and Meidani, 1998).

\begin{tabular}{lccccccr}
\hline Borehole & \multicolumn{2}{c}{ UTM (Zone 39 Datum) } & $\begin{array}{c}\text { Discharge } \\
\left(\mathrm{m}^{3} \mathrm{~s}^{-1}\right)\end{array}$ & $\begin{array}{c}\text { Well } \\
\text { Depth }(\mathrm{m})\end{array}$ & $\begin{array}{c}\text { Depth to Water } \\
\text { Table }(\mathrm{m})\end{array}$ & $\begin{array}{c}\text { Thickness of the } \\
\text { Aquifer }(\mathrm{m})\end{array}$ & $\begin{array}{c}\text { Distance from the } \\
\text { Pumping Well }(\mathrm{m})\end{array}$ \\
\hline QR 8 & 707531.06 & 3158326.57 & 0.04 & 95 & 12.2 & 82.8 & 0.0 \\
QR 49 & 707537.38 & 3158306.96 & 0.0 & 85 & 24.3 & 60.7 & 20.6 \\
QR 47 & 707486.08 & 3158302.52 & 0.0 & 140 & 7.4 & 132.6 & 51.0 \\
QR 22 & 707410.91 & 3158379.07 & 0.0 & 200 & 7.1 & 192.9 & 131.1 \\
QR 28 & 707630.22 & 3158423.13 & 0.0 & 80 & 11.6 & 68.4 & 138.4 \\
QR 25 & 707324.44 & 3158345.80 & 0.0 & 180 & 66.0 & 114.0 & 207.5 \\
QR 55 & 707447.01 & 3158121.73 & 0.0 & 90 & 8.4 & 81.6 & 221.4 \\
\hline
\end{tabular}


Table 3. Estimation of hydraulic conductivity from tracer tests analysis using formulas $v=x / t_{c}$ and $v=K i / n$.

\begin{tabular}{lcrrrrr}
\hline Tracer Test & $x(\mathrm{~m})$ & $t_{c}(\mathrm{~d})$ & $v\left(\mathrm{~m} \mathrm{~d}^{-1}\right)$ & $i\left(\mathrm{~m} \mathrm{~m}^{-1}\right)$ & Reynolds Number & $K\left(\mathrm{~m} \mathrm{~d}^{-1}\right)$ \\
\hline QR 51 to Springs diversion tunnel & 850 & 42 & 20.2 & 0.0330 & 28.0 & 64.7 \\
QR 32 to QR 28 & 220 & 14 & 15.7 & 0.0052 & 21.8 & 319.0 \\
QR 32 to The river at the location of the dam & 160 & 7 & 22.9 & 0.0108 & 31.7 & 223.4 \\
QR 28 to QR 8 & 140 & 60 & 2.3 & 0.0049 & 3.2 & 50.3 \\
QR 28 to QR 55 & 230 & 62 & 3.7 & 0.0081 & 5.1 & 48.3 \\
Geometric mean & 249.3 & - & - & - & - & 102.3 \\
\hline
\end{tabular}

diameter $D$, where $\rho$ is the density of the fluid and $\mu$ is the dynamic viscosity of the fluid (Chanson, 2004). Laminar flow dominates when the Reynolds number is less than about 2,300, known as the critical Reynolds number, in pipe flow (Shaughnessy et al., 2005). However in karst terrains, laminar flow becomes unstable at Reynolds numbers in excess of 1,500 and transitions to turbulent flow at Reynolds numbers above 6,000 (Veress, 2010). Calculated groundwater flow Reynolds numbers were well within the laminar flow Reynolds numbers at the SFDS (Table 3). Application of the Darcian Flow Law $v=K i n^{-1}$, where $K$ is the hydraulic conductivity and $i$ is the hydraulic gradient, is suitable only within the laminar flow regime.

The hydraulic conductivity was calculated for the five successful tracer paths tabulated in Table 3, one of which, QR 28 to QR 8 (Fig. 2), also provided pumping test data. Reynolds number $(\leq 30)$ were well within laminar flow limits, and hydraulic conductivity ranged from 50 to about 320 $\mathrm{m} \mathrm{d}^{-1}$ (Table 3). The flow directions of the successful tracer tests (Table 3, Fig. 2) generally follow the topography (Fars Regional Water Authority, 1994); the tracers moved toward the dam site.

\section{Pumping And Lugeon Tests}

To calculate the hydrodynamic coefficients of the aquifer, the analytical models provided by Moench (1984) and Barker (1988) were applied in the study area. Dewandel et al. (2005) proposed that Moench's model for a dual-porosity

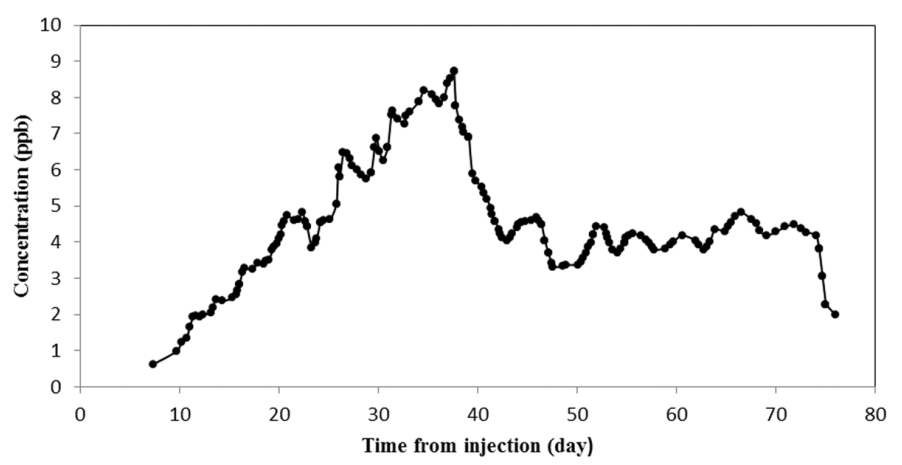

Figure 3. Breakthrough curve of Rhodamin B in the QR 51 to springs diversion tunnel dye trace (Khalaj Amirhosseini, 1997). media is consistent with most of the pumping tests in karst aquifers.

The diagnostic plots showed that boundary interference was not evident in any of the test data at the SFDS. The diagnostic plots, such as those in Figures 4 and 5, of the observation wells suggested Moench's analytical model for the observation wells QR 49 and QR 47 and Barker's analytical model for the observation wells QR 22, QR 28, QR 25, and QR 55 (Fig. 2).

Hydraulic conductivity was calculated for the six monitoring wells based on the pumping test at QR 8 . One path has data from both the tracer test and pumping test. Hydrodynamic coefficients of the aquifer were calculated using AQTESOLV (Duffield, 2007). Hydraulic conductivities from the pumping tests ranged from 8 to $160 \mathrm{~m} \mathrm{~d}^{-1}$ with a geometric mean of $30 \mathrm{~m} \mathrm{~d}^{-1}$ (Table 4).

Hydraulic conductivity was also determined from three Lugeon, or packer, tests. Results were reported in Lugeon unit $\left(\mathrm{L}_{\mathrm{u}}\right)$ around the boreholes QR 22, QR 28, and QR 32. Approximately $1 \mathrm{~L}_{\mathrm{u}}$ is $0.1 \mathrm{~m} \mathrm{~d}^{-1}$ in fractured rocks (Kovács, 1981). Hydraulic conductivities from the Lugeon tests ranged from 0.02 to $75 \mathrm{~m} \mathrm{~d}^{-1}$ (Table 5).

\section{Discussion}

The results of the estimated hydraulic conductivity are presented in Tables 3, 4, and 5. The wide range of hydraulic conductivity is representative of the notable local heterogeneity in the karst aquifer at the Salman Farsi Dam Site. The geometric means of the hydraulic conductivity were 100 and $30 \mathrm{~m} \mathrm{~d}^{-1}$ for tracer and pumping tests, respectively. From the Lugeon tests, the mean hydraulic conductivity was $3.8 \mathrm{~m} \mathrm{~d}^{-1}$. The Lugeon tests are important because they are much more sensitive to the rock matrix, in great contrast to the tracer tests, which are dominated by flow in conduits and fractures. The geometric mean of the hydraulic conductivity obtained by the tracer tests was three and a half times greater than the pumping test results. Greater values for the geometric mean of the hydraulic conductivity in the tracer tests may be due to the scale effect (Király, 1975), because the geometric mean of the distances in the tracer tests $(249.3 \mathrm{~m})$ is more than the geometric mean of the distances in the pumping test $(97.8 \mathrm{~m})$ and Lugeon tests $(30 \mathrm{~m}$ according to Bliss and Rushton, 1984). In other words, on a longer distance scale, the role of macrofractures and dissolution openings increases in 


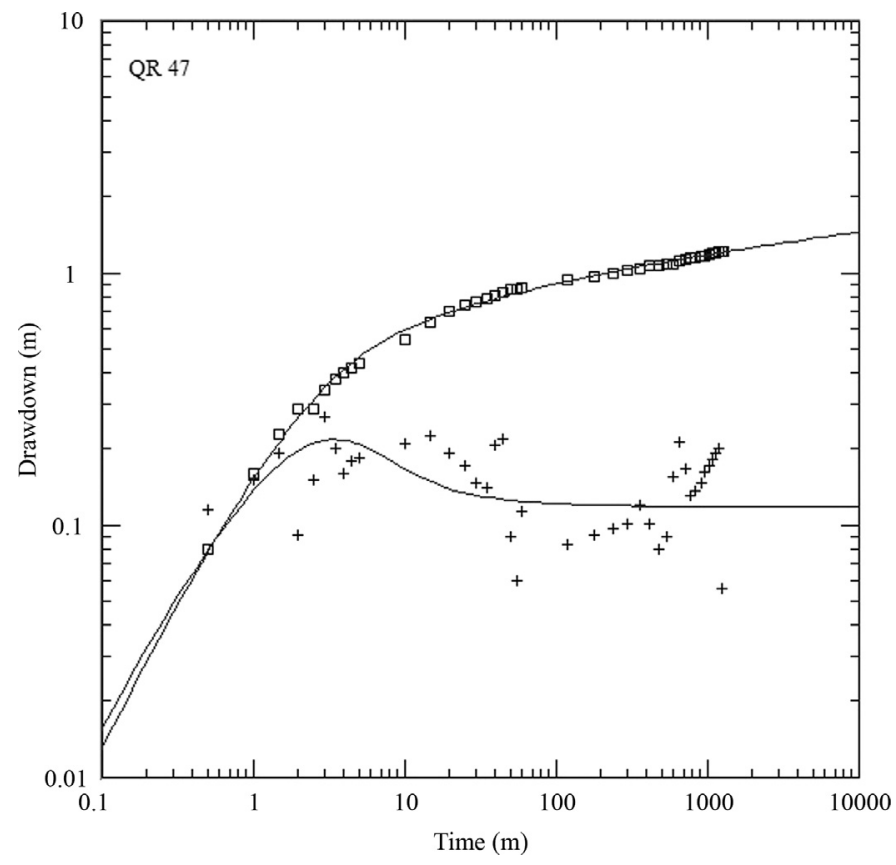

Figure 4. Moench (1984) analytical model is suggested for the observation well QR 47 based on this diagnostic plot from the pumping test ( $\square$ amount of drawdown; + derivative of drawdown).

karst terrain, so it is expected that the hydraulic conductivity should increase, too. In the path QR 28 to QR 8 common to both tests, the hydraulic conductivities were 50 and $30 \mathrm{~m} \mathrm{~d}^{-1}$ based on the tracer and pumping tests, respectively. Different values for hydraulic conductivity in one path may be due to the different hydraulic behavior of groundwater flow in the karst terrain during tracer and pumping tests. In a pumping test, groundwater mainly flows from the both macrofractures and matrix (Moench, 1984; Maréchal et al., 2008), while in a tracer test groundwater and dissolved dye mainly flow via the macrofracture and dissolution openings routes toward the observation points (Gouzie et al., 2010). In other words, transmission of dye in anisotropic media in tracer test is mainly via routes with minimum head loss (Salgado-Castro, 1988; Nassimi, 2011) such as dissolution-created channel and conduit (macrofracture) routes, while in a pumped well

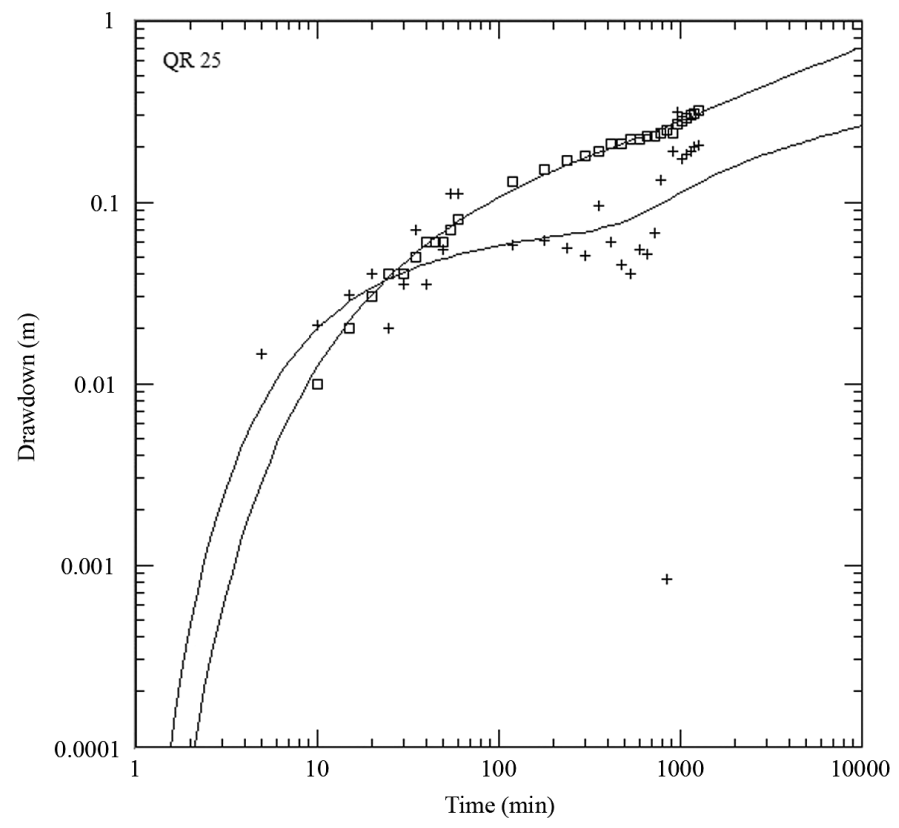

Figure 5. Barker (1988) analytical model is suggested for the observation well QR 25 based on this diagnostic plot from the pumping test ( $\square$ amount of drawdown; + derivative of drawdown).

that taps anisotropic media, groundwater flows through both macrofractures and matrices in the cone of depression (Moench, 1984). The heterogeneous karst terrain at the SFDS is composed of many dissolution openings including caves, channels, and shafts that have been enlarged along geological discontinuities such as bedding planes, joints, and shear fractures. These structural elements developed as conduit routes play a major role for groundwater flow.

In the Burnham field site, near Christchurch on the South Island of New Zealand, "the combined use of pumping and tracer test data enabled the derivation of equivalent average hydraulic conductivities $\left(K_{\text {avg }}\right)$ for each test in a heterogeneous channelized alluvial aquifer, whereas $K$ values of the preferential flow paths were two orders of magnitude higher" (Dann et al., 2008). Also $K$ estimated from tracer test was six times greater than the $K_{\text {avg }}$ estimated from a pumping test in a stratified aquifer at the Bonita, California, field site (Thorbjarnarson et al., 1998).

Table 4. Estimation of hydraulic conductivity from analysis of pumping test using Moench (1984) and Barker (1988) analytical models.

\begin{tabular}{lcccr}
\hline Borehole & Distance from the Pumping Well $(\mathrm{m})$ & Analytical Model & Transmissivity $\left(\mathrm{m}^{2} \mathrm{~d}^{-1}\right)$ & $K_{\text {ave }}\left(\mathrm{m}^{2} \mathrm{~d}^{-1}\right)$ \\
\hline QR 49 & 20.6 & Moench (1984) & 522.0 & 8.6 \\
QR 47 & 51.0 & Moench (1984) & $2,347.0$ & 17.7 \\
QR 22 & 131.1 & Barker (1988) & $3,723.0$ & 19.3 \\
QR 28 & 138.4 & Barker (1988) & $1,976.8$ & 28.9 \\
QR 25 & 207.5 & Barker (1988) & $6,748.8$ & 59.2 \\
QR 55 & 221.4 & Barker (1988) & $13,105.0$ & 160.6 \\
Geometric mean & 97.8 & - & - & 30.5 \\
\hline
\end{tabular}


Table 5. Estimation of hydraulic conductivity from Lugeon test.

\begin{tabular}{|c|c|c|c|}
\hline Borehole & Depth, m & $\begin{array}{c}\text { Hydraulic } \\
\text { Conductivity, } \\
\mathrm{L}_{\mathrm{u}}\end{array}$ & $\begin{array}{c}\text { Hydraulic } \\
\text { Conductivity } \\
\mathrm{m} \mathrm{d}^{-1}\end{array}$ \\
\hline QR 22 & $\begin{array}{c}13-18 \\
18-23 \\
23-28 \\
28-33 \\
33-38 \\
38-43 \\
43-48 \\
48-53 \\
53-58 \\
58-63 \\
63-68 \\
68-73 \\
73-78 \\
78-83 \\
83-88 \\
88-93 \\
93-98 \\
98-103 \\
103-108 \\
108-113 \\
113-118 \\
118-123 \\
123-128 \\
128-133 \\
133-138 \\
138-143 \\
143-148 \\
148-153\end{array}$ & $\begin{array}{r}31.8 \\
748.2 \\
4.2 \\
1.7 \\
1.3 \\
0.8 \\
2.1 \\
17.0 \\
0.6 \\
22.9 \\
0.5 \\
5.0 \\
10.6 \\
14.9 \\
30.8 \\
35.9 \\
11.8 \\
2.1 \\
11.2 \\
8.9 \\
13.9 \\
2.0 \\
1.9 \\
1.3 \\
1.8 \\
25.3 \\
0.6 \\
0.7\end{array}$ & $\begin{array}{r}3.2 \\
74.8 \\
0.4 \\
0.2 \\
0.1 \\
0.1 \\
0.2 \\
1.7 \\
0.1 \\
2.3 \\
0.1 \\
0.5 \\
1.1 \\
1.5 \\
3.1 \\
3.6 \\
1.2 \\
0.2 \\
1.1 \\
0.9 \\
1.4 \\
0.2 \\
0.2 \\
0.1 \\
0.2 \\
2.5 \\
0.1 \\
0.1\end{array}$ \\
\hline QR 28 & $\begin{array}{l}33-37 \\
37-40 \\
40-45 \\
45-50 \\
50-55 \\
55-60 \\
60-65 \\
65-70 \\
75-80\end{array}$ & $\begin{array}{r}12.8 \\
11.9 \\
0.2 \\
10.3 \\
13.5 \\
22.3 \\
77.2 \\
2.3 \\
2.7\end{array}$ & $\begin{array}{r}1.3 \\
1.2 \\
0.02 \\
1.0 \\
1.4 \\
2.2 \\
7.7 \\
0.2 \\
0.3\end{array}$ \\
\hline QR 32 & $\begin{array}{r}5.7-10.7 \\
10.7-15.7 \\
15.7-20.7 \\
20.7-25.7 \\
25.7-30.7\end{array}$ & $\begin{array}{r}111.6 \\
28.3 \\
127.9 \\
75.4 \\
75.7\end{array}$ & $\begin{array}{r}11.2 \\
2.8 \\
12.8 \\
7.5 \\
7.6\end{array}$ \\
\hline Mean & - & - & 3.8 \\
\hline
\end{tabular}

Hydraulic conductivity is dominated by the development of karst features in a karst terrain. Different approaches are introduced to overcome the wide range of hydraulic conductivity in karst terrains. At the SFDS, with notable conduit and joint systems, the data received from the tracer test demonstrate the dual porosity with preferential flow paths, while the data obtained by the pumping test would cause considerable underestimation of hydraulic conductivity due to the effects of preferential flow paths in the tracer test and solute transport.

\section{Conclusions}

Hydraulic conductivity was estimated as about 100,30 , and $3.8 \mathrm{~m} \mathrm{~d}^{-1}$ based on the tracer, pumping and Lugeon tests, respectively, in the study area. The $K$ estimated from tracer tests was approximately three and half times greater than the $K_{\text {avg }}$ estimated from the pumping test. In a karst terrain, the estimated value of $K$ based on a tracer test is more representative of groundwater flow velocities than those based on the pumping and Lugeon tests, due to the dominant role of preferential flow paths in the tracer test in comparison to the pumping test. The observed results are consistent with a dual porosity continuum and are not unexpected in a karst system. Assuming transmission of tracer by preferential flow paths in the scale of basins in the heterogeneous karst terrain, the value of hydraulic conductivity based on the tracer test is greater than that given by dual porosity analysis of pumping tests. The development of karst features played a major role in the hydraulic conductivity in the study area. As a result, for areas with preferential flow paths, such as karst aquifers, the hydraulic conductivity obtained from tracer tests are greater than the hydraulic conductivity obtained from pumping test.

\section{AcKnowledgements}

The authors thank the University of Shiraz for their support of this work. Also some of hydrogeology data of the study area was supplied by Fars Regional Water Authority in Shiraz. The authors thank the Journal of Cave and Karst Studies Associate Editors and Advisory Board for their encouragement and constructive criticism.

\section{REFERENCES}

Aghili, B., and Meidani, A., 1998, Report of pumping test of karstic wells at the Salman Farsi Dam Site: Mahab Ghodss consulting engineering company, Fars regional water authority, 62 p. (in Persian).

Barenblatt, G.I., Zheltov, Iu.P., and Kocina, I.N., 1960, Basic concepts in the theory of seepage of homogeneous liquids in fissured rocks [strata]: Journal of Applied Mathematics and Mechanics, v. 24, no. 5 , p. 1286-1303. doi:10.1016/0021-8928(60)90107-6.

Barker, J.A., 1988, A generalized radial flow model for hydraulic tests in fractured rock: Water Resources Research, v. 24, no. 10, p. 1796-1804. doi:10.1029/WR024i010p01796.

Benischke, R., Goldscheider, N., and Smart, C., 2007, Tracer techniques, in Goldscheider, N., and Drew, D., eds., Methods in Karst Hydrogeology: London, Taylor \& Francis, IAH International Contributions to Hydrogeology 26, p. 147-170.

Bliss, J.C., and Rushton, K.R., 1984, The reliability of packer tests for estimating the hydraulic conductivity of aquifers: Quarterly Journal of Engineering Geology and Hydrogeology, v. 17, no. 1, p. 81-91. doi:10.1144/GSL.QJEG.1984.017.01.10. 
Bourdet, D., Whittle, T.M., Douglas, A.A., and Pirard, Y.M., 1983, A new set of type curves simplifies well test analysis: World Oil, v. 196 , p. $95-106$.

Cacas, M.C., Ledoux, E., de Marsily, G., Tillie, B., Barbreau, A., Durand, B., Feuga, B. and Peadecerf, P., 1990, Modeling fracture flow with a stochastic discrete fracture network: Calibration and validation: 1 . The flow model: Water Resources Research, v. 26, no. 3, p. 479-489. doi:10.1029/WR026i003p00479.

Chanson, H., 2004, The Hydraulics of Open Channel Flow: An Introduction: Basic Principles, Sediment Motion, Hydraulic Modelling, Design of Hydraulic Structures, second edition: Oxford, Butterworth-Heinemann, $634 \mathrm{p}$

Dann, R.L., Close, M.E., Pang, L., Flintoft, M.J., and Hector, R.P., 2008, Complementary use of tracer and pumping tests to characterize a heterogeneous channelized aquifer system in New Zealand: Hydrogeology Journal, v. 16, no. 6, p. 1177-1191. doi:10.1007/s10040-008-0291-4.

De Laguna, W., 1970, Tracer aids interpretation of pumping test: Water Resources Research, v. 6, no. 1, p. 172-184. doi:10.1029/ WR006i001p00172.

De Waele J., Gutiérrez F., Parise M., and Plan, L., 2011, Geomorphology and natural hazards in karst areas: A review: Geomorphology, v. 134, no. 1-2, p. 1-8. doi:10.1016/j.geomorph.2011.08.001.

Dewandel, B., Lachassagne, P., Boudier, F., Al-Hattali, S., Ladouche, B., Pinault, J.-L., and Al-Suleimani, Z., 2005, A conceptual hydrogeological model of ophiolite hard-rock aquifers in Oman based on a multiscale and a multidisciplinary approach: Hydrogeology Journal, v. 13, no. 5-6, p. 708-726. doi:10.1007/s10040-005-0449-2.

Drew, D., and Goldscheider, N., 2007, Combined use of methods, in Goldscheider, N., and Drew, D., eds., Methods in Karst Hydrogeology: London, Taylor \& Francis, p. 223-228.

Duffield, G.M., 2007, AQTESOLV (pumping tests, constant-head tests and slug tests) Software for Windows. Version 4.5, User's Guide: Reston, Virginia, HydroSOLVE Inc., 530 p.

Fars Regional Water Authority, 1990, Report of geology at the Salman Farsi Dam Site: Mahab Ghodss consulting engineering company, 71 p. (in Persian).

Fars Regional Water Authority, 1994, Report of studies at the Salman Farsi Dam Site: Mahab Ghodss consulting engineering company, $869 \mathrm{p}$.

Fars Regional Water Authority, 1995a, Report the results of experiments on rock samples of the Salman Farsi Dam Site: Khak \& Sang civil work contractor \& geotechnical consultant company, 274 p. (in Persian).

Fars Regional Water Authority, 1995b, Report of the results of Lugeon tests at the Salman Farsi Dam Site: Khak \& Sang civil work contractor \& geotechnical consultant company, 243 p. (in Persian).

Fazeli, M.A., 2007, Construction of grout curtain in karstic environment case study: Salman Farsi Dam: Environmental Geology, v. 51, no. 5, p. 791-796. doi:10.1007/s00254-006-0397-8.

Ghasemizadeh, R., Hellweger, F., Butscher, C., Padilla, I., Vesper, D., Field, M., and Alshawabkeh, A., 2012, Review: Groundwater flow and transport modeling of karst aquifers, with particular reference to the North Coast Limestone aquifer system of Puerto Rico: Hydrogeology Journal, v. 20, no. 8, p. 1441-1461. doi:10.1007/s10040-0120897-4.

Gouzie, D., Dodd, R.P., and White, D.M., 2010, Dye-tracing studies in southwestern Missouri, USA: Indication of stratigraphic flow control in the Burlington Limestone: Hydrogeology Journal, v. 18, no. 4, p. 1043-1052. doi:10.1007/s10040-010-0581-5.

Gringarten, A.C., 1982, Flow test evaluation of fractured reservoirs, in Narasimhan, T.N., ed., Recent Trends in Hydrogeology: Geological Society of America special paper 189, p. 237-263. doi:10.1130/ SPE189-p237.

Gutiérrez, F., Parise, M., De Waele, J., and Jourde, H., 2014, A review on natural and human-induced geohazards and impacts in karst: Earth Science Reviews, v. 138, p. 61-88. doi:10.1016/j.earscirev.2014. 08.002 .

Hammond, P.A., and Field, M.S., 2014, A reinterpretation of historic aquifer tests of two hydraulically fractured wells by application of inverse analysis, derivative analysis, and diagnostic plots: Journal of Water Resource and Protection, v. 6, no. 5, p. 481-506. doi:10.4236/jwarp. 2014.65048.

Hestir, K., and Long, J.C.S., 1990, Analytical expressions for the permeability of random two-dimensional Poisson fracture networks based on regular lattice percolation and equivalent media theories: Journal of Geophysical Research: Solid Earth, v. 95, no. B13, p. 21565-21581. doi:10.1029/JB095iB13p21565.

Khalaj Amirhosseini, Y., 1997, Report of tracer tests at the Salman Farsi Dam Site: Water Research Center of the Ministry of Power, Fars Regional Water Authority, 68 p. (in Persian).

Király, L., 1975, Rapport sur l'état actuel des connaissances dans le domaine des caracteres physique des roches karstique, in Burger, A., and Dubertet, L., eds., Hydrogeology of Karstic Terrains: Paris, International Union of Geological Sciences, series B, number 3, p. $53-67$.

Kovács, G., 1981, Seepage Hydraulics: Amsterdam, Elsevier, Developments in Water Science 10, $730 \mathrm{p}$.

Kovács, A., and Sauter, M., 2007, Modelling karst hydrodynamics, in Goldscheider, N., and Drew, D., eds., Methods in Karst Hydrogeology: London, Taylor \& Francis, p. 201-222.

Lee, Jin-Yong, Kim, Jung-Woo, Cheon, Jeong-Yong, Yi, Myeong-Jae, and Lee, Kang-Kim, 2003, Combined performance of pumping and tracer tests: A case study: Geosciences Journal, v. 7, no. 3, p. 237-241. doi:10.1007/BF02910290.

Löfgren, M., Crawford, J., and Elert, M., 2007, Tracer Tests - Possibilities and Limitations. Experience from SKB Fieldwork: 1977-2007: Swedish Nuclear Fuel and Waste Management Co., SKB report R-07-39, $121 \mathrm{p}$.

Maréchal, J.C., Ladouche, B., Dörfliger, N., Lachassagne, P., 2008, Interpretation of pumping tests in a mixed flow karst system: Water Resources Research, v. 44, no. 5, paper W05401. doi:10.1029/2007 WR006288.

Milanovic, P., 2002, The environmental impacts of human activities and engineering constructions in karst regions: Episodes, v. 25, no. 1, p. 13-21.

Milanović, P., Kreuzer, H., Dolder, T., 2002, Report on design of the Grout Curtain, Salman Farsi Dam Project in Iran: Mahab Ghodss consulting engineering company, Fars Regional Water Authority, $202 \mathrm{p}$.

Moench, A.F., 1984, Double-porosity models for a fissured groundwater reservoir with fracture skin: Water Resources Research, v. 20, no. 7, p. 831-846. doi:10.1029/WR020i007p00831.

Mohammadi, Z., Bagheri, R., Jahanshahi, R., 2010, Hydrogeochemistry and geothermometry of Changal thermal springs, Zagros region, Iran: Geothermics, v. 39, no. 3, p. 242-249. doi:10.1016/j.geothermics.2010. 06.007 .

Nassimi, A., 2011, Groundwater: Tehran, Dibagaran Tehran, 300 p. (in Persian).

Nazari, M.H., 2008, Sealing the karst cavity base on the scale at the Salman Farsi Dam Site, in Proceedings of 2nd National Conference on Dam and Hydropower, May 14-15, Tehran, Ministry of Power, p. 1-9 (in Persian)

Niemann, W.L., and Rovey, II, C.W., 2000, Comparison of hydraulic conductivity values obtained from aquifer pumping tests and conservative tracer tests: Groundwater Monitoring \& Remediation, v. 20, no. 3, p. 122-128. doi: 10.1111/j.1745-6592.2000.tb00278.x.

Parise, M., De Waele, J., and Gutierrez, F., 2008, Engineering and environmental problems in karst - An introduction: Engineering Geology, v. 99, no. 3-4, p. 91-94. doi:10.1016/j.enggeo.2007.11.009.

Parise, M., Closson, D., Gutiérrez, F., and Stevanović, Z., 2015a, Anticipating and managing engineering problems in the complex karst environment: Environmental Earth Sciences, v. 74, no. 12, p. $7823-$ 7835. doi:10.1007/s12665-015-4647-5.

Parise, M., Ravbar, N., Živanović, V., Mikszewski, A., Kresic, N., Mádl-Szőnyi, J., and Kukurić, N., 2015b, Hazards in karst and managing water resources quality, in Stevanovic, Z., ed., Karst Aquifers - Characterization and Engineering: Cham, Switzerland, Springer, p. 601-687. doi:10.1007/978-3-319-12850-4_17.

Rahbari, A., and Bagheri, S., 1996, Report on the geology and geomorphology in the Salman Farsi Dam Catchment: Jihad Engineering Services Co. and Parsab Consulting Engineers, Ministry of Agriculture Jihad, 225 p. (in Persian).

Renard, P., Glenz, D., and Mejias, M., 2009, Understanding diagnostic plots for well-test interpretation: Hydrogeology Journal, v. 17, no. 3, p. 589-600. doi:10.1007/s10040-008-0392-0.

Rovey, II, C.W., and Niemann, W.L., 2005, Do conservative solutes migrate at average pore-water velocity?: Groundwater, v. 43, no. 1, p. 52-62. doi:10.1111/j.1745-6584.2005.tb02285.x. 
Salgado-Castro, R.O., 1988, Computer modelling of water supply distribution networks using the gradient method [Ph.D. thesis]: Newcastle upon Tyne, Newcastle University, $419 \mathrm{p}$.

Samani, N., Pasandi, M., and Barry, D.A., 2006, Characterizing a heterogeneous aquifer by derivative analysis of pumping and recovery test data: Journal of Geological Society of Iran, v. 1, p. 29-41.

Shaughnessy, E.J., Jr., Katz, I.M., and Schaffer, J.P., 2005, Introduction to Fluid Mechanics: New York, Oxford University Press, $1057 \mathrm{p}$.

Streltsova-Adams, T.D., 1978, Well hydraulics in heterogeneous aquifer formations: Advances in Hydroscience, v. 11, p. 357-423. doi:10. 1016/B978-0-12-021811-0.50011-5.

Taheri, K., Taheri, M., and Parise, M., 2015, Unprotected karst resources in western Iran: the environmental impacts of intensive agricultural pumping on the covered karstic aquifer, a case in Kermanshah province: Geophysical Research Abstracts, v. 17, p. 1640.
Thorbjarnarson, K.W., Huntley, D., and McCarty, J.J., 1998, Absolute hydraulic conductivity estimates from aquifer pumping and tracer tests in a stratified aquifer: Groundwater, v. 36, no. 1, p. 87-97. doi:10.1111/ j.1745-6584.1998.tb01068.x.

Vandenbohede, A., and Lebbe, L., 2003, Combined interpretation of pumping and tracer tests: theoretical considerations and illustration with a field test: Journal of Hydrology, v. 277, p. 134-149. doi:10. 1016/S0022-1694(03)00090-8.

Veress, M., 2010, Karst Environments: Karren Formation in High Mountains: Dortrecht, Springer, 238 p. doi:10.1007/978-90-4813550-9.

Vucković, D., and Milanović, S., 2001, Report on the speleological investigation (mission report) at the Salman Farsi Dam Site: Mahab Ghodss consulting engineering company, Fars Regional Water Authority, $35 \mathrm{p}$. 